\title{
Membangun Brand Perguruan Tinggi Melalui Marketing Public Relations
}

\author{
Adie Kurbani \\ Manajemen, Fakultas Ekonomi Universitas PGRI Palembang \\ adie78kurbani@univpgri-palembang.ac.id
}

\begin{abstract}
ABSTRAK
Memiliki dan melahirkan brand yang besar dan kuat tentu menjadi idaman semua pelaku bisnis termasuk didalamnya perguruan tinggi. Merek (brand) berfungsi mengidentifikasi barang atau jasa dari seorang atau sekelompok penyaji dan membedakannya dari produk sejenis dari penyaji lain. Penelitian ini bertujuan untuk melihat bagaimana upaya membangun brand perguruan tinggi melalui Marketing Publik Relations. Penelitian ini menggunakan pendekatan kualitatif dengan metode deskriptif. Adapun hasilnya adalah Marketing Publik Relations memiliki keunggulan dibanding periklanan dalam membangun merek (brand) dan telah banyak tokoh pemasaran yang menyarankan untuk membangun merek (brand) terutama merek (brand) baru dengan menggunakan MPR bukan dengan periklanan. Keunggulan MPR dibandingkan periklanan selain berbiaya lebih murah adalah lebih dapat dipercaya sehingga akan memudahkan membangun citra positif dibenak konsumen (calon mahasiswa).
\end{abstract}

Kata Kunci : Brand, Perguruan Tinggi, Marketing Public Relations

\section{A. PENDAHULUAN}

Terjadi perubahan yang sangat besar dalam dunia pemasaran khususnya setelah munculnya konsep merek sebagai aset kunci perusahaan atau perguruan tinggi. Tidak hanya perusahaan, perguruan tinggi ternyata memerlukan merek (brand) sebagai modal untuk dikenal di masyarakat. Pertimbangan ini terlihat dengan meningkatnya peranan brand dalam riset pemasaran (Malhotra, Peterson \& Kleiser, 1999) dan manajemen praktis (Aaker 1996; Murphy 1998), dimana hasil dari pertemuan dua konsep teoritis tersebut mengarah pada bidang manajemen strategik dan pemasaran. Lebih lanjut didapatkan bahwa terjadi redefinisi ulang persepsi secara akademis maupun manajerial tentang peran dan pentingnya brand dalam pembentukan strategi (Kapferer 1992; Mintzberg, Quinn \& Ghoshal, 1998). Niall Fitzgerald, co-chairman dari UNILEVER, sebuah perusahaan grup kolaborasi Inggris dan Belanda menyadari perubahan ini saat mengatakan "We're not a manufacturing company any more, we're a brand marketing group that happens to make some of its products " (Willman, 2000). Stephen King dari WPP Group London juga mengatakan "A product is something that is made in factory; a brand is something that is bought by a customer. A product can be copied by a competitor; a brand is unique. A product can be quickly outdated; a successful brand is timeless".

Secara umum merek (brand) yang kuat adalah (1) berharga, yaitu dalam pengembangan mereka dapat membantu perguruan tinggi untuk membuka peluang/kesempatan (melalui brand extension) dan menetralisir ancaman lingkungan persaingan; (2) jarang dimiliki oleh kompetitor saat ini maupun kompetitor potensial; (3) mahal untuk ditiru dan (4) tidak ada pengganti/substitutor strategis (Barney, 1991). Coca Cola \& 
Starbucks menggunakan corporate brand Coca Cola atau biasa dikenal sebagai Coke, Starbucks menggunakan nama yang sama untuk semua kafe-kafenya di seluruh dunia sedangkan HM Sampoerna dengan beberapa mereknya yang terkenal $\mathrm{Dji}$ Sam Soe \& A-Mild (X-Mild, Sampoerna Exclusive \& Sampoerna Hijau tidak dimasukkan dalam kategori merek kuat karena masih merupakan merek yang masih berusaha dibangun oleh perusahaan). Sedangkan untuk perguruan tinggi tentu memakai namanama terkenal seperti afiliasi terhadap organisasi besar misalnya, Nahdatul Ulama, Muhammadyah, Persatuan Guru Republik Indonesia (PGRI) atau nama-nama besar lainnya.

Banyak orang percaya bahwa isu fundamental dalam pemasaran adalah meyakinkan calon konsumen bahwa perusahaan atau perguruan tinggi memiliki produk atau jasa yang lebih baik. Kata-kata yang sering muncul adalah 'Kita mungkin bukan yang pertama tetapi kita akan menjadi yang lebih baik'. Hal ini mungkin benar, tetapi jika perusahaan terlambat masuk ke dalam pasar dan harus bersaing dengan pesaing-pesaing besar yang lebih mapan, maka strategi pemasaran perusahaan mungkin tidak tepat. Strategi 'meniru' tidak akan efektif (Jack Trout, 2002). Bagaimanapun, The Law of Leadership dari 22 immutable laws of marketing mengatakan 'It is better to be the first in the market than to be the better' (Ries \& Trout, 1994). Di Indonesia, data menunjukkan beberapa pionir sukses yang hingga saat ini masih mendominasi pasar, misalnya Aqua (industri air mineral dalam kemasan), Sanyo (pompa air), Teh Botol Sosro (teh botol), Baygon (pembasmi nyamuk), Honda (sepeda motor), Coke (minuman cola), Gillette (pisau cukur) dan Sony (produk elektronik).

Memiliki dan melahirkan brand yang besar dan kuat tentu menjadi idaman

semua pelaku bisnis termasuk didalamnya perguruan tinggi. Merek (brand) berfungsi mengidentifikasi barang atau jasa dari seorang atau sekelompok penyaji dan membedakannya dari produk sejenis dari penyaji lain (Kotler, 2000:163). Lebih dari itu, merek adalah sesuatu yang dibentuk dalam pikiran pelanggan dan memiliki kekuatan membentuk kepercayaan pelanggan (Peter \& Olson, 1996:168). Jika perusahaan mampu membangun merek yang kuat di pikiran pelanggan melalui strategi pemasaran yang tepat, perusahaan akan mampu membangun mereknya. Dengan demikian merek dapat memberi nilai tambah pada nilai yang ditawarkan oleh produk kepada pelanggannya yang dinyatakan sebagai merek yang memiliki ekuitas merek (Aaker,1991:14).

\section{B. KAJIAN PUSTAKA}

\section{1) Strategi Pengelolaan Merk (Brand)}

Sebuah produk adalah sesuatu yang secara potensial dinilai oleh pasar sasaran berdasarkan keuntungan atau kepuasan yang tersedia, yang meliputi objek, jasa,organisasi, tempat, orang dan idea. Keahlian khas para pemasar profesional adalah kemampuan mereka menciptakan, memelihara, melindungi, dan meningkatkan merek produk dan jasa mereka. Merek adalah suatu nama, kata, tanda, simbol, atau desain, atau kombinasi dari semuanya yang mengidentifikasi pembuat atau penjual produk dan jasa tertentu. Konsumen melihat merek sebagai bagian produk yang penting dan merek dapat menambah nilai produk. 
$\begin{array}{llr}\text { Barangkali } & \text { ketrampilan } & \text { pemasar } \\ \text { profesional } & \text { yang paling } & \text { menonjol } \\ \text { adalah } & \text { kemampuan } & \text { untuk }\end{array}$ menciptakan, menjaga, melindungi dan menaikkan citra merek. Asosiasi

Pemasaran Amerika (the American Marketing Association) mendefinisikan merek atau brand sebagai nama, istilah, tanda, simbol, desain, atau kombinasinya, yang ditujukan agar dapat mengenali barang atau jasa dari satu atau sekelompok penjual dan membedakannya dari produk dan jasa para pesaing. Berdasarkan peraturan perundangundangan merek dagang, penjual tersebut diberikan hak eksklusif untuk menggunakan nama mereknya selamanya. Merek berbeda dengan aset lainnya seperti hak paten atau hak cipta yang memiliki tanggal kadaluarsa. (Kotler, 2004) Adalah penting untuk membedakan produk dan merek. Suatu citra merk yang kuat memberikan beberapa keunggulan utama bagi suatu perusahaan. Pada prakteknya kadang-kadang produk dan merek bisa saling menggantikan, walaupun sebenarnya mempunyai arti yang berbeda. Sebuah produk adalah sesuatu yang secara potensial dinilai oleh sebuah pasar sasaran untuk keuntungan dan kepuasan yang disediakan, terdiri dari objek, jasa, oeganisasi, tempat, orang dan ide-ide.

Menurut Aaker (1997) terdapat tiga nilai yang diberikan merk yaitu :

a) Nilai fungsional yang diperoleh dari atribut-atribut produk,

b) Nilai emosional yang diperoleh dari perbandingan dengan merkmerk lain yang bersaing. Nilai emosional dirasakan pada saat konsumen membeli, menggunakan dan menikmati atau mengkonsumsi suatu merk.

c) Nilai ekspresi diri yaitu pembelian produk merupakan ekspresi diri konsumen.
Nilai emosional dan ekspresi diri dapat mengurangi kekurangan nilai fungsional sebagai contoh pada saat kita mengkonsumsi Bebek Goreng Slamet yang berlokasi di Mall dibandingkan dengan Bebek Goreng Slamet yanga berlokasi di Batur Raden dengan udara dan pemadangan alam yang indah.

\section{2) Strategi Pemberian Merk (Brand)}

Berbagai strategi pemberian merk (Cravens, 1996) yaitu

a. Tanpa identitas merk .

Perusahaan kecil dan sedang banyak yang tidak memiliki identitas merk yang mapan walaupun nama perusahaan tertera dalam kemasan atau barangnya. Hal ini karena keterbatasan sumber daya finansial dan kemampuan pemasaran mengakibatkan perusahaan sulit nenbangun citra merknya. Mereka mengandalkan para grosir dan pengecer untuk mempromosikan produknya.

b. Pemberian merk sendiri

Pengecer dengan nama merk yang sudah mapan dapat mengadakan pernjanjian dengan produsen untuk menempatkan merk-merk pengecer pada produk-produk yang dibuat. Pemberian merk ini sering disebut privat branding sebagai contoh kapas bermerk Alfa. Hal ini bertujuan untuk membangun loyalitas toko. Bagi produsen mengurangi biaya pemasaran.

c. Pemberian merk perusahaan

Strategi ini membanggun identitas merk dengan menggunakan nama korparasi untuk identifikasi seluruh produk yang ditawarkan. Keunggulannya menggunakan 
satu periklanan dan program promosi penjualan untuk mendukung semua produk perusahaan. Kelemahannya adalah kurangnya fokus pada produk tertentu dan efek merugikan pada seluruh portofolio produk jika perusahaan menghadapi publisitas negatif.

d. Pemberian merk lini produk Strategi ini menempatkan nama produk pada suatu lini produk yang berkaitan pemberian merk lini produk memberikan lebih banyak perhatian dari pada merk korporasi dan akanlebih efektif bila mempromosikan seluruh produk dari pada satu persatu.

e. Pemberian merk khusus

Strategi pemberian merk pada suatu produk tertentu yang sering dibeli konsumen. Nama merk pada sebuah produk memberikan suatu identitas khusus barangbarang tersebut di pasar. Suatu merk yang berhasil akan membangun loyalitas konsumen yang kuat sepanjang masa.

f. Kombinasi

Perusahaan menggunakan kombinasi strategi pemberian merk di atas.

\section{METODE PENELITIAN}

Ditinjau dari jenis datanya pendekatan penelitian yang digunakan dalam penelitian ini adalah pendekatan kualitatif. Adapun yang dimaksud dengan penelitian kualitatif yaitu penelitian yang bermaksud untuk memahami fenomena tentang apa yang dialami oleh subjek penelitian secara holistik, dan dengan cara deskripsi dalam bentuk kata-kata dan bahasa, pada suatu konteks khusus yang alamiah dan dengan memanfaatkan berbagai metode ilmiah (Moleong, 2007). Adapun jenis pendekatan penelitian ini adalah deskriptif. Penelitian deskriptif yaitu penelitian yang berusaha untuk menuturkan pemecahan masalah yang ada sekarang berdasarkan data-data. Jenis penelitian deskriptif kualitatif yang digunakan pada penelitian ini dimaksudkan untuk memperoleh informasi mengenai langkah-langkah membangun brand sebuah perguruan tinggi dengan menggunakan metode marketing public relation. Selain itu, pendekatan secara kualitatif diharapkan dapat menggali terkait permasalahan yang muncul dalam membangun brand perguruan tinggi.

\section{PEMBAHASAN}

Jalan atau sarana dasar yang digunakan Public Relations (PR) adalah mengoperasikan word-of-mout, media cetak, berita TV, dan rekomendasi pribadi. Tujuannya adalah untuk menempatkan perusahaan termasuk didalamnya sebuah universitas dan produknya ke dalam pikiran dan percakapan orang dengan cara yang positif. Karena informasi muncul sebagai berita, cenderung dapat mempengaruhi lebih kuat. Public Relations (PR) bukan iklan, karena tidak dibayar untuk secara langsung (meskipun biasanya ada beberapa biaya yang melekat dalam hal membayar seseorang untuk menulis press release, dan juga dalam menciptakan sebuah berita (Blythe, 2005). Banyak orang yang berfikir bahwa merek dibangun menggunakan periklanan (advertising). Kotler (2003) mengatakan bahwa advertising hanya menimbulkan perhatian terhadap merek. Lebih lanjut Kotler (2003) mengatakan bahwa merek dibangun secara holistik, melalui kombinasi berbagai alat meliputi advertising, public relations, sponsorships, events, social causes, clubs, spokespersons dan sebagainya. Salah satu hal yang menjadi topik menarik disini adalah 
bagaimana public relations atau marketing public relation berperan dalam membangun suatu merek. Banyak perguruan tinggi mengalokasikan dana yang terlalu besar untuk periklanan dan sedikit untuk public relation (Kotler, 2003). Padahal untuk membangun merek (brand), lebih tepat menggunakan public relations dibandingkan menggunakan Public Relations (PR). Seperti apa yang Kotler (2003) katakan "I expect companies to start shifting more money from advertising to public relations. Advertising is losing some of its former effectiveness. It is hard to reach a mass audience because of increasing audience fragmentation. TV commercials are getting shorter; they are bunched together; they are increasingly undistinguished; and consumers are zapping them".

Sebaiknya perguruan tinggi mulai berani untuk mengalokasikan dana lebih besar pada public relations dibandingkan untuk periklanan. Kotler (2003) berpendapat bahwa advertising telah kehilangan banyak efektivitasnya yang dulu. Ini membuat advertising sulit mencapai audiens yang besar karena meningkatnya fragmentasi audiens. Kotler (2003) menambahkan "The biggest problem is that advertising lacks credibility. The public knows that advertising exaggerates and is biased. At its best, advertising is playful and entertaining; at its worst, it is intrusive and dishonest".

Masalah terbesar periklanan adalah tidak memiliki kredibilitas. Disamping itu, publik kini tahu bahwa apa yang periklanan promosikan adalah dilebih-lebihkan dan bias. Hal tersebut diperburuk lagi dengan anggapan publik bahwa periklanan adalah ganguan dan tidak jujur. Lebih lanjut Kotler (2003) mengatakan bahwa membangun merek baru melalui Public Relations (PR) lebih baik dari pada menggunakan advertising meskipun membutuhkan kreativitas dan waktu yang lebih lama. Perguruan tinggi yang berencana membangun brand baru perlu menciptakan buzz, dan buzz diciptakan melalui alat Public Relations (PR). Menggunakan kampaye Public Relations (PR) akan membuat biaya jauh lebih sedikit dan memungkinkan membuat cerita yang lebih kekal (Kotler: 2003). Menurut Blythe (2005), Public Relations (PR) yang baik akan lebih efektif dibandingkan periklanan karena alasan-alasan berikut:

1. The press coverage is free, so there is better use of the promotional budget.

2. The message carries greater credibility because it is in the editorial part of the paper.

3. The message is more likely to be read, because while readers tend to skip past

4. The advertisements, their purpose in buying the paper is to read the news stories.

Banyak bukti menunjukan bahwa public relations lebih baik dalam membangun merek. Perusahaan seperti Palm, Amazon, eBay, The Body Shop, Blackberry, Beanie Babies, Viagra, and Nokia, mereka membangun merek tidak melalui periklanan tetapi melalui berita di media cetak dan di udara. mereka menggunakan Public Relations (PR), bukan periklanan (Kotler, 2003). Lalu apakah tugas atau peran public relation bagi perusahaan dan produk serta merek-nya. Kotler dan Keller (2009) mengajukan enam tugas atau peran PR yang juga disebut marketing public relation (MPR), karena penggunaan Public Relations (PR) pada bidang marketing. Tugas atau peran tersebut adalah:

1. Launching new products. 
2. Repositioning a mature product

3. Building interest in a product category

4. Influencing specific target groups

5. Defending products that have encountered public problems

6. Building the corporate image in a way that reflects favorable on its products.

Marketing Public Relation (MPR) atau Public Relation (PR) dalam menjalankan perannya perlu seperangkat alat untuk mencapai tujuan yang telah ditetapkan sebelumya dalam hal ini adalah upaya membangun merek terutama merek baru. Kotler dan Keller (2009) menyebutkan tujuh peralatan utama dalam Marketing Public Relation (MPR), yaitu:

1. Publications.

2. Events

3. Sponsorships

4. News

5. Speeches

6. Public service activities

7. Identity media.
Dalam bukunya yang lain, Kotler (2003) memberikan tujuh peralatan Marketing Public Relation (MPR) yang dia sebut sebagai "the Pencils of Public Relations" dimana peralatan ini dapat digunakan untuk merebut perhatian dan menciptakan "talk value." The pencils of public relations tersebut adalah:

1. Publications.

2. Events.

3. News.

4. Community affairs.

5. Identity media.

6. Lobbying.

7. Social investments.

Peralatan Marketing Public Relation (MPR) lainnya diusulkan oleh Burnett (2003), berisi sepuluh teknik public relations, yaitu News release (press release), Press conference, Delivering bad news, Publicity photographs, Company publications, Open house/tours, Meeting, Organized social activities, Participation, dan Motion pictures/slides. Kesepuluh teknik public relations beserta penjelasannya dapat dilihat dalam tabel 1.

Tabel 1. Teknik Public Relations

\begin{tabular}{|c|c|}
\hline TECHNIQUE & DESCRIPTION \\
\hline 1. News release (press release) & - A prepared statement sent to various media. \\
\hline 2. Press conference & - Meeting attended by media representatives for \\
\hline 3. Delivering bad news & $\begin{array}{l}\text { - System that anticipates and handles negative } \\
\text { events. }\end{array}$ \\
\hline Publicit & A prepared photo sent to various media. \\
\hline 5. Company publications & $\begin{array}{l}\text { - Magazines, newspapers, and newsletter } \\
\text { produced by the company, depicting specific } \\
\text { stories. }\end{array}$ \\
\hline 6. Open house/tours & $\begin{array}{l}\text { - Providing various publics' acces to plant } \\
\text { facilities. }\end{array}$ \\
\hline 7. Meeting & $\begin{array}{l}\text { - Planned meeting provided for various publics, } \\
\text { especially employees and stockholders. }\end{array}$ \\
\hline 8. Organized social activities & ed social activities directed \\
\hline
\end{tabular}


9. Participation

10. Motion pictures/slides

Sumber : Burnett (2003)

Semua peralatan Marketing Public Relation (MPR) baik dari Kotler dan Keller (2009), Kotler (2003), maupun Burnett (2003) yang telah disebutkan sebelumnya, tidaklah jauh berbeda, adapun perbedaan yang ada akan saling melengkapi sehingga memperkaya peralatan Marketing Public Relation (MPR) yang ada. Selanjutnya kembali kepada pemasar untuk meramu dan menggunakan berbagai peralatan Marketing Public Relation (MPR) yang ada untuk mencapai tujuan pemasaran ataupun membangun merek suatu produk.

\section{E. KESIMPULAN DAN SARAN}

Setiap produk membutuhkan merek (brand), termasuk perguruan tinggi, karena merek (brand) lah yang diingat dan nantinya dipilih oleh konsumen. Merek (brand) digunakan untuk mengenali atribut produk dan juga untuk membedakannya dengan pesaing. Selain itu sifat merek (brand) yang termasuk penting adalah "pengaruh," dengan kekuatan pengaruhnya, merek memengaruhi calon mahasiswa serta dapat mengabarkannya kepada calon mahasiswa lain selanjutnya. Seperti pendapat Kapferer (2009) dalam The New Strategic Brand Management, untuk membuat merek (brand) yang memiliki pengaruh dibutuhkan aktivitas pemasaran untuk membentuk asosiasi mental dibenak calon mahasiswa dan hubungan antara merek (brand) dengan calon mahasiswa yang dibangun sepanjang masa. Merek (brand) yang memiliki nilai psikologi dan finansial disebut ekuitas merek dimana merek tersebut akan membangun loyalitas pelanggannya. Merek dan kualitas saja tidak cukup.

Diperlukan komunikasi pemasaran untuk menyampaikan pesan yang tepat pada calon mahasiswa yang tepat. Tanpa komunikasi maka perguruan tinggi akan tenggelam diantara banyaknya perguruan tinggi lainnya, sehingga telah menjadi kebutuhan mutlak bagi perguruan tinggi untuk menggunakan komunikasi pemasaran untuk memperkenalkan kampusnya serta memengaruhi calon mahasiswa. Salah satu komponen komunikasi pemasaran yang memiliki peran besar dalam membangun merek adalah public relations atau marketing public relation. Marketing public relations memiliki keunggulan dibanding periklanan dalam membangun merek (brand) dan telah banyak tokoh pemasaran yang menyarankan untuk membangun merek (brand) terutama merek (brand) baru dengan menggunakan Marketing Public Relation (MPR) bukan dengan periklanan. Keunggulan Marketing Public Relation (MPR) dibandingkan periklanan selain berbiaya lebih murah adalah lebih dapat dipercaya sehingga akan memudahkan membangun citra positif dibenak konsumen (calon mahasiswa).

\section{DAFTAR PUSTAKA}

Aaker, A. 1996. Manajemen Ekuitas Merek, Memanfaatkan Nilai dari 
Suatu Merek : Terjemahan Edisi Pertama. Jakarta : Mitra Utama

Aaker, D.AA. 1991. Managing Brand Equity: Capitalizing on the Value of a Brand Name. New York: The Fre Press.

Blythe, Jim. 2005. Essentials Of Marketing. 3th edition. Edinburgh Gate:

Pearson Education Limited.

Burnett, John. 2003. Core Concept Of Marketing, 2th Edition. New York: John Wiley.

Craven, David W. 1996. Pemasaran Strategis. Jakarta: Penerbit Erlangga.

Kapferer, J. N. 2008. The New Strategic Brand Management. 4th edition. Great Britain: Kogan Page Limited.
Kotler, Philip dan Kevin Lane Keller. 2008. Manajemen Pemasaran Edisi

13 Jilid 1. Jakarta: Penerbit Erlangga.

Kotler, Philip dan Gary Armstrong. 2008. Prinsip-prinsip Pemasaran Edisi 12 Jilid 2. Jakarta: Penerbit Erlangga.

Ries, A \& J. Trout. 2003. The 22 Immutable Laws of Marketing. New York : Harper Collins Publisher Inc.

Trout, Jack. 2001. Big Brands Big Trouble. John Wiley \& Sons

Philip Kotler. 2003. Marketing Insights From $A$ To $Z$, 10th edition. New Jersey: John Wiley \& Sons, Inc.

Philip Kotler \& Kevin L. Keller. 2009. Marketing Management, 13th edition. New Jersey: Pearson Education, Inc. 